\title{
RELIGIOUS DISCOURSES AND POLICIES TOWARDS THE PALESTINIAN-ISRAELI CONFLICT: A COMPARISON OF TURKEY AND IRAN
}

\section{Filistin- İsrail Çatışmasına Yönelik Dini Söylem ve Politikalar: Türkiye ve İran Üzerine Bir Karşılaştırma}

\author{
Dr. Öğr. Üyesi M. Hüseyin Mercan \\ ORCID: 0000-0003-4699-0700/Marmara Üniversitesi, Siyaset Bilimi ve Uluslararası Iliş̧kiler Bölümü. \\ Arş. Gör. Haris Ubeyde Dündar \\ ORCID: 0000-0002-8614-0551/ Erciyes Üniversitesi, Uluslararası Ilişkiler Bölümü.
}

A R T I C L E I N F O
Article history:
Received: 27 October 2021
Accepted: 26 November 2021
Keywords: Turkey, Iran, Religion,
Foreign Policy Discourse, Palestinian-
Israeli Conflict.

Israeli Conflict.

\section{Makale geçmişi:}

Başvuru tarihi: 27 Ekim 2021

Kabul tarihi: 26 Kasım 2021

Anahtar Kelimeler: Türkiye, İran, Din, Dış Politika Söylemi, Filistin-İsrail Çatışması.

\section{ABSTRACT}

Considering that Palestinian-Israeli conflict is one of the cases in the current international system that is predominantly shaped by the religion factor, it is an important question how and to what extent both Turkey and Iran legitimize their strategies using religious discourse. Although both states rely on Islamic beliefs in their approaches towards the cause of Palestinians and both utilize religious rhetoric extensively to shore up their domestic support, they differ in how in their discourses and policies towards Israel. In this regard, the study first discusses the current literature on the role of religion in foreign policy and international relations. Then, how religious values and beliefs have informed the foreign policy discourse and behavior of Turkey and Iran with specific focus on the Palestinian-Israeli issue are discussed.

\section{öz}

Mevcut uluslararası sistemde din-siyaset ilişkisinin en açık şekilde görüldüğü vaka olarak Filistinİsrail meselesi düşünüldüğünde hem Türkiye hem de İran'ın dini referanslar yoluyla hayata geçirdikleri stratejileri nasıl ve ne düzeyde meşrulaştırdıkları önemli bir sorudur. Özellikle tarafların Filistin yaklaşımları benzer olmakla beraber her iki ülkenin İsrail'e yönelik tavır ve söyleminde dini referansların kullanımının boyut değiştirmesi bu karşılaştırmayı daha anlamlı hale getirmektedir. Bu bağlamda makalede öncelikle dinin dış politika ve uluslararası ilişkilerdeki rolüne dair gelişen literatürün bir tartışması yapılacak sonrasında ise Türkiye ve İran'ın Filistin-i̇srail meselesini dini argümanlar üzerinden nasıl gördüğü ardından da her iki ülkenin bu meseleye yaklaşımında dinin nasıl bir rolü olduğu derinlemesine tartışılacaktır.

\footnotetext{
* Sorumlu yazar/Corresponding author.
} e-posta: huseyin.mercan@marmara.edu.tr. 


\section{INTRODUCTION}

The establishment of a new political order based on the principle of secular sovereignty with the Peace of Westphalia resulted in the omission of the decisive influence of religion and references to the sacred in international relations for a very long time. However, serious challenges to the nature of international order in the last few decades have given rise to a new interest in the role of religion in global politics. The more frequent use of religious texts and teachings than in the past have encouraged a vast literature discussing the role of religion in international relations. Actually, the fact that the phenomenon of religion has come to the fore more in the global system or political movements whose actions and discourses are based on religious teachings have become more significant does not mean that the nature of the modern political order has been radically transformed. However, it has become clear that religious rhetoric has become one of the most effective tools for legitimizing the actions of nation-states pursuing their interests within the parameters of the Westphalian international order.

Building on the generally accepted notion that religion is an important source used by regimes and governments to legitimate their rule, to persuade and motivate their public, we can say that religious values, norms, and discourse also play a very important role in inter-state relations. Religion in this way gets transformed into a functional tool that creates opportunities for foreign policy makers and/or ensures their preservation of the status quo particularly in countries where religious precepts have a predominant influence on social and political structures. It is hard to overlook how religious discourses have become the core element of these states' strategies towards certain foreign policy issues or regions. Especially, examples such as the Palestinian-Israeli conflict, many states use the religion as a source of legitimacy both in domestic politics and international relations, better explain the "revival of religion" in recent years and its role in foreign policy-making processes.

In the light of the discussion above, this article is a comparative analysis of the role of religious rhetoric in the policies of Turkey and Iran towards Palestinian-Israeli conflict, in the post-9/11 period when religion's influence has increased on a global scale. Considering that Palestinian-Israeli conflict is one of the cases in the current international system that is predominantly shaped by the religion factor, it is an important question how and to what extent both Turkey and Iran legitimize their strategies using religious discourse. Although both of these states rely on Islamic beliefs in their approaches towards the cause of Palestinians and both utilize religious rhetoric extensively to shore up their domestic support, they differ in how in their discourses and policies towards Israel. Contrary to Turkey's approach to the Palestinian-Israeli conflict, which recognizes Israel's right to exist and is more peaceful, Iran's behavior has been hostile towards Israel, which denies its right to exist. Through this comparison, this article posits that the use of religious arguments towards the same issue differ among these cases as a result of the interaction between the domestic and international political contexts and the policy goals of the Turkish and Iranian governments. To this end, this article first discusses the current literature on the role of religion in foreign policy and international relations. Then, how religious values and beliefs have informed the foreign policy discourse and behavior of Turkey and Iran with specific focus on the Palestinian-Israeli issue are discussed.

\section{Religion and Foreign Policy in International Relations Literature}

The Westphalian order, which is accepted as the beginning of modern international relations and in which the principles of war, peace and trade began to be established not according to religious rules and principles, but according to the state system (Philpott, 2000, p. 207) positioned religion far from the center for a long time in the field of international relations. However, studies emphasizing the relationship between religion and international relations (Berger, 1999; Fox \& Sandler, 2004; Haynes, 2007; Hurd, 2008; Norris \& Inglehart, 2004; Petito \& Hatzopoulos, 2003; Snyder, 2011; S. M. 
Thomas, 2005; Toft et al., 2011) began to question the belief that sees religion as a 'primitive' element in the context of modernity and not having a place in modern society. This scholarship not only challenged the assumptions of the Westphalian order, which confined religion to the individual sphere as an external element, but also the theories of modernization and secularization which constitute the infrastructure of modern international relations. Especially international developments involving cultural and identity factors in the second half of the 20th century strengthened the arguments stating that, as Kratochwil also emphasized, the actions of leaders are influenced by ideas, ideologies and values, and these actions play a role in determining the practices and preferences of states in foreign policy and international relations (Koslowski \& Kratochwil, 1994, p. 11; Kratochwil, 2006, p. 216; Fox \& Sandler, 2005). Thus, scholarly interest has been renewed in the role of religion, understood as a value and belief system, in shaping the foreign policies of states and more generally international relations, which challenges the position attributed to religion by modern and secular assumptions.

In this respect, macro level analysis that include religion in the discussion of the reinterpretation of the international system and relations between states have been offered and attracted great attention. While Fukuyama's "End of History" (Fukuyama, 1992) one of the most popular of these studies, tried to strengthen the prevalent assumption religion's inconsequential role against those questioning it, Huntington placed religion at the center of international relations and foreign policy with his "Clash of Civilizations" (Huntington, 1993b, 1996). This controversial work gained popularity once again after $9 / 11$ attacks when the discussions on the role religion in international politics have proliferated especially in the analysis of terrorism, conflict, and violence. The period marking the reemergence of religion in human thought and culture signifies to the 'return' of religion to international relations. This return is not only a transformation of the private sphere in the form of an increase in individual religiosity, but also a questioning of the political structure and secularism, affecting international relations at a wider level.

Although the phenomenon of 'religious resurgence' in international relations was treated negatively within the framework of terrorism due to the effect of $9 / 11$, its variety of roles in foreign policy also began to be discussed in a broader framework (Fox \& Sandler, 2005; Johnston, 2003; Johnston et al., 1994; Juergensmeyer, 2003; Stern, 2003). Studies in this direction have paved the way for religion to become an element that "deserves more attention in international relations" (Fox, 2001; Fox \& Sandler, 2004, 2005) and to be included in international relations theory.

As previously mentioned, the discussion of the role of religion in international relations is also a re-examination of modernization and secularization theories. One of the reasons why religion has been considered as an inconsequential factor has been the basic assumption of secularization theory, which is that developments in certain fields will gradually make religion unimportant in the world, and therefore religion is/will be an ineffective, powerless and unscientific factor (Fox \& Sandler, 2005). According to the secular assumption, as a result of modernization, there will be a decrease in religious beliefs and practices, religion will become secularized and become an individual issue, and it will lose its ability to regulate social life or, at best, will have a symbolic value (Riesebrodt, 2000). Secularism, which has become the main source of political authority and one of the pillars of modern politics, as a result of developments in European history and science (Hurd, 2004, p. 241) has seen religion as an enemy and obstacle in modern politics, and as a source of identity and unity that causes conflict in modern international relations. Thus, the idea was that secularism, as the essence of Euro-American history, civilization and culture should be promoted as a unique Western achievement, whereas religion, as a source of identity, is the underlying deterrent for development and engenders conflict and resistance (Hurd, 2008, p. 23). 
This view has been challenged by many scholars stating that modernism has constituted a 'political myth' that excludes religion, spiritual and sacred mechanisms from the system (S. M. Thomas, 2003, pp. 21-25), that religion has never been truly excluded from the political sphere, but rather an evolution has taken place from religious political forms to secular ones through the secularization of pre-modern theological concepts (Schmitt, 2005, p. 36), that only the role of religion has changed and secularism has not saved human life from the controlling power of religion, and that secularism has not replaced religion, but rearranged it within the political and social sphere (Asad, 2003, pp. 191-200; Berger, 1999). Similarly, the point that the assumptions of secular and modern theory on religion are valid only for continental Europe and the Western world has also been made. Religion has not been separated from international politics as it was presented and envisaged in the non-Western world such as Turkey, India, Africa and Iran, and it did not lose its influence and was completely confined to the individual sphere. Although it had a weak presence in the Western world, it continued to exist strongly in the non-Western world (Haynes, 1994, 2005, p. 401; Hurd, 2008, p. 137; S. M. Thomas, 2003, p. 45)

Although scholarly works on the role of religion within the narratives of secular and modern politics have not ended the conceptualization of international relations as secular, they have led to the incorporation of the effects of culture, values and beliefs on actions, and thus, on foreign policy into account. Although the tendency to reduce religion to individual belief has been widely accepted for a long time, it is problematic in terms of understanding the current international relations and thus studies that bring religion back into focus in this field are important steps to remedy this problem. As Hurd points out, "religious resurgence" which denotes actions, movements and processes that challenge the authoritarian secular interpretations of the relationship between metaphysics, politics and state power, has led to the blurring of boundaries between the religious and the secular (Hurd, 2008 , p. 135). Therefore, it is no longer possible and beneficial to persistently and definitively separate and contrast the sacred and the mundane.

In the international system, states do not carry out strategies only through concrete means in order to maximize their interests. On the contrary, sometimes alternative sources of legitimization are drawn upon to enable states to pursue their policies and expand their spheres of influence on certain issues. At this point, religion gains an exceptional position in foreign policy as a means of legitimization, mobilization, and motivation, in addition to its social influence. Scott Thomas discusses four main contexts when classifying what religion corresponds to or how it is understood in international relations: a form of ideology, a form of identity, a type of transnational idea, and religion as a form of soft power (S. Thomas, 2000, pp. 1-8). In particular, the identity-building aspect of religion plays an important role in policy makers' more frequent use of religious references in the face of global or regional developments. As a matter of fact, Huntington clearly states the influence of religion in the international system with the following emphasis: "In the modern world, religion is central, perhaps the central force that motivates and mobilizes people (Huntington, 1993a, pp. 191-192)".

It can be observed that as religion's influence and import in the world system has increased, it has also become a new foreign policy tool alongside the traditional ones such as military and economic power. Fox and Sandler define this new tool states may find functional to use in foreign policy, as "persuasion" and state that the path towards convincing others to believe in your argument or strategy goes through legitimization (Fox \& Sandler, 2004, p. 36). Considering that legitimacy is always one of the most important pillars of political processes, foreign policies implemented by religious references generate a novel context for legitimacy. Building on the argument that religion is an important source of legitimacy and has the power to legitimize both governments and their policies (Fox \& Sandler, 2004, p. 36), we can posit that states are faced with a more inundated foreign policy arena compared to the 
periods when international relations developed on a more secular basis since religion is no longer only a parameter that shapes the life of individuals and society, but also a fundamental factor that affects the policy making and preferences of those who run the state (Luttwak, 1995, p. 9). This condition inevitably induces political actors to use arguments intertwined with religious discourses more frequently in foreign policy to ensure their legitimacy.

The increase in the popularity of religion as a source of legitimacy is most concretely encountered what used to be called third world countries, i.e., post-colonial states. Western secular ideologies have acquired a negative connotation in these contexts because of their failure to deliver on their promises of prosperity and development. Therefore, the religious resurgence has had the effect of weakening secularism as a source of legitimacy in third world countries. Fox and Sandler list the reasons for this transformation as follows. First, secular ideologies were associated with foreign influence and control imposed by Westernized rulers. Secondly, regimes that have adhered to these ideologies failed in their promises of freedom, development, and social justice. Thirdly, the modernization policies of these governments have led to the alienation of groups excluded from the process. Another reason is that modern communication facilities have allowed religious institutions to expand their sphere of influence. Modernization has had an adverse effect of increasing the political opportunities for religious groups to be integrated into the system. Likewise, religious freedom has led to an increase in individual interest in religion (Fox \& Sandler, 2004, p. 38). These reasons enabled the resurgence of religion along with its adoption as a source of legitimacy.

Religious arguments used by governments or leaders to persuade the public not only allow for legitimization of policies, but also pave the way for the production of a pragmatic political discourse or strategy. What should not be overlooked here also is that religious discourse often plays a role in expanding the range of action of decision makers. For example, in Iran, as Haynes puts it, where the first modern religion-centered revolution in history took place, (Haynes, 2008, p. 156) the new regime has adopted a religious identity oriented foreign policy understanding and often raised the tone of political discourse to as pragmatic stratagem to persuade the public. The fact that anti-Westernism has become one of the main foreign policy parameters in post-revolution Iran is directly related to the religious-based strategy devised by the rulers. In this case, religious discourse functions not only as the most potent tool for mobilizing and motivating the people in realizing a political transformation or overcoming an existing crisis, but also offers a great opportunity for the government to maintain the status quo.

Religious rhetoric has been frequently used by Iran, the U.S. and Israel in international relations in the modern era. For example, right after the Islamic Revolution, Ayatollah Khomeini defined the USA as the "Great Satan" to legitimize the regime itself and its foreign policy. Similarly, the Reagan administration tried to legitimize its struggle against the enemy state of the time, the USSR, by defining it as the "Empire of Evil". During the period when the U.S. was determining its new enemies in the Middle East, George W. Bush defined the countries of Iran and Iraq along with their proxies as the "Axis of Evil" (S. Thomas, 2000, p. 3).

The most recent and striking example of the use of religion in foreign policy as a legitimating force was seen in President Bush's "War on Terror" declaration after 9/11. Bush stated after the attacks of 9/11 that a global war against terrorism would be waged and the conduct of this struggle was a mission given by God (Bush, 2002). In the following years, the U.S. foreign policy was shaped on this premise. The war between Iran and Iraq lasting from 1980 to 1988 can be cited as another example for the legitimization of war through the use of religious rhetoric similar to the declaration of "war on 
terrorism" by the United States. Although both are Muslim states, this war has been defined by Iran with concepts such as "holy war" and "holy defense" (Taleblu, 2014).

With the failure of Arab nationalism in the post-colonial period, religious identity began to surpass nationalism in the Middle East. Due to the Bush Doctrine, religion started to be used as an important element of identity and to legitimize power and foreign policy not only in the Middle East and Islamic world, but also in other regions. Experiences since the last years of the Cold War lifted the veil of religion leading it to regain its former importance as an important determinant in international relations and foreign policy (Haynes, 2008, pp. 149-150).

As shown, religion has acquired a very dominant role in foreign policy for the legitimacy of the ruler and the persuasion and motivation of the ruled. The question of Palestine, as an example of a conflict rooted in religion from the time of emergence to its subsequent phases is crucial both to understand the kinds of arguments the ruler make for legitimation and the kinds of social pressures on the government to take an action. Thus, analyzing the ways in which Turkey and Iran- two countries where religion is at the center of society and politics- use religious arguments and pursue pragmatic strategies informed by religion for legitimacy in their policies toward Palestine and Israel will contribute to a better grasp of the intricacies and depth of the relationship between religion and foreign.

\section{Religious Discourse in Turkey's Approach to the Palestinian-Israeli Conflict}

In an atmosphere where global politics was reshaped and religious references increased after the September 11 attacks, an important transformation took place in Turkish political life. After the Justice and Development Party (AK Party), whose founders were mostly Islamists, came to power in 2002, new topics of discussion arose in the country. Foremost political questions during this period were how the party would improve relations with the Islamic world and how the state would remain secular (Ozkan, 2013, p. 534). While strategies the new government would devise in domestic politics were debated among different ideological lenses, in foreign policy, Turkey re-imagined its position between the West and the Muslim world. The new foreign policy vision aimed to transform Turkey's position as a bridge between two worlds to a "central country" that is able to assert its own will in the international system (Davutoğlu, 2008, p. 78) and directly be involved in the developments in global politics.

Especially the religious and historical background played an important role in putting forward this new foreign policy vision. As a matter of fact, Ahmet Davutoğlu, one of the most influential figures determining the foreign policy philosophy of the AK Party period, endeavored to develop a new narrative of Turkey's historical and geographical location ${ }^{1}$. Drawing from Islamic thought Davutoglu devised a new rhetoric and strategy for a world order that took into account the Ottoman experience. Although this style of politics, which blends Islamic values and Turkish tradition, is not new in Turkish political life, both the changing global political dynamics and the strong domestic power of the AK Party have strengthened a foreign policy discourse in which religious references are frequently used. The following statement by Davutoğlu contain important clues about the new discursive context and reference points in Turkey's view of global:

“...wherever there is a global problem, we would like to have a Turkish outlook there, a Turkish stance, a Turkish viewpoint. Since we come from the Nizam-ı Alem, a tradition of world order,

\footnotetext{
${ }^{1}$ For details on Davutoğlu's vision of Turkey's position in the international system; (Davutoğlu, 2004; 2007)
} 
we must have basic principles about the global order besides these regional orders. (Dış İ̧leri Bakanı Davutoğlu'nun Konuşması, 2011)"

Davutoglu's use of the Islamic concept of Nizam-I Alem ${ }^{2}$ points to the effort to present an alternative approach to international relations drawing from the Islamic notion of world order when he is formulating Turkey's new foreign policy perspective. In the final analysis, this has opened the door for Turkey to produce foreign policy strategies with an Islamic tone both discursively and institutionally. In particular, the new role assigned to the Presidency of Religious Affairs' beyond representing religious authority in developing Turkey's relations with the Muslim world contributed to the strengthening of a faith-based diplomacy in foreign policy. ${ }^{3}$

Among the foreign policy issues Turkey deals with, the Palestinian- Israeli conflict is undoubtedly where the use of religious rhetoric is most prevalent. In particular, calls for action by the international community regarding the protection of the status of Jerusalem and Haram al-Sharif and the constant criticism of Israeli occupation make up the core of Turkey's policy towards Palestine. We can observe that President Recep Tayyip Erdoğan's messages of support for Palestine are laden with Islamic rhetoric. Through the use of religious expression, Erdoğan aims in fact both to increase the impact of his discourse and to increase his legitimacy at the local, regional and global levels. Following the Israeli administration's expansionist and aggressive attempt to change the status of Jerusalem in May 2021, the following messages by Erdogan exemplify how Turkey's stance on Palestine was strengthened through religious references:

\begin{abstract}
"The attack in Jerusalem was on every Muslim who circumambulates the Kaaba in Mecca and presents himself before the Prophet (SAW- peace be upon him) in Medina along with our [Palestinian] brothers. The subject of this attack is every single Muslim living in Istanbul, Diyarbakir, Baghdad, Cairo, Islamabad, Jakarta, Kuala Lumpur, Baku and Sarajevo. I invite the whole world, especially Islamic countries, to take effective action against Israel's attacks on AlAqsa Mosque, Jerusalem and the homes of Palestinians."

"It is the duty of every Muslim to protect the honor, dignity, honor and dignity of Jerusalem. ... A world that cannot protect Jerusalem and Muslims means that it has betrayed itself and pulled the pin of the grenade of self-destruction. Today, Turkey stands by our brothers in Jerusalem and all Muslims in Palestine as always. ...We want the vile attacks on Masjid al-Aqsa in Jerusalem, against Muslims, to be stopped immediately. We expect an end to all direct and indirect pressures aimed at displacing Palestinians from their homes and their homes. Allah is the helper of the oppressed and the victims.(Cumhurbaşkanı Erdoğan'dan Mescid-i Aksa Çağrısı, 2021)"
\end{abstract}

Erdogan's statements include a reminder for the entire Muslim world of its responsibility towards Jerusalem and Masjid al-Aqsa, while at the same time an ultimatum to Israel through the use of Islamic expressions. In particular, with the phrase "God is the helper of the oppressed and the victims", he wants to send a special message with an emphasis on "the day of judgement" and expresses hope that the oppressed and aggrieved Palestinians will win against Israel with the help of Allah. Moreover, Erdoğan's proposal for Jerusalem to be governed by a commission consisting of representatives of three religions following the attacks in May (Son Dakika Cumhurbaşkanı Erdoğan'dan Kudüs Teklifi, 2021) stressed the need for a religious foundation to play an important role in determining the political future of Jerusalem. Considering the vital importance of Jerusalem for all

\footnotetext{
${ }^{2}$ Nizam-ı Alem is an idea of World order theorized by Ottomans as legitimizing discourse with a specific reference to justice and Islamic political theory which were adopted to Ottomans' administrative practice. See for a discussion on the concept; (Hagen, 2005)

${ }^{3}$ For a study on the role of the Presidency of Religious Affairs in Turkish foreign policy, (Ozkan \& Chatterjee, 2019, pp. 117-121)
} 
three monotheistic religions, the prominent role of religion in shaping Turkey's policy towards both Palestine and Israel is clear.

Turkey's approach with regards to the ongoing developments of the Palestinian-Israeli conflict has always been in favor of establishing a lasting peace. This is evident in all of the AK Party governments' programs as well as all official statements in the international arena. Turkey's policy towards the Palestinian-Israeli conflict involves a strategy based on sustaining relations with both parties, and thus religious discourse is only used after incidents of Israeli government's aggression influenced by Zionist ideology. While Erdogan does not hesitate to issue harsh statements after Israel's attacks on Gaza, also makes a clear distinction between Zionism and Judaism and targets the crimes committed by the Israeli state and its rulers. In a speech delivered in Austria in 2013, Erdoğan stated that Zionism should be "considered a crime against humanity" and he always condemned antiSemitism. He further emphasized that he did not have a problem with the Jews and that all his criticisms were directed towards Zionist thought (Erdoğan "Siyonizm" ile ilgili Sözlerine Açıklık Getirdi, 2013). Similarly, by meeting with the delegation of the Jewish Anti-Zionist League during his stay in New York to attend the UN General Assembly meeting in 2019 (Cumhurbaşkanı Erdoğan Siyonizme Karşı Yahudiler Birliği Heyetini Kabul Etti, 2019). Erdoğan aimed to show the whole world that Turkey's use of religious discourse and actions toward the Palestinian issue are not aimed against the Jews, but Zionists who aim to establish a great Jewish State with Jerusalem as the capital.

It is important to bear in mind that Turkey's use of religious discourse in its policy towards the Palestinian- Israeli conflict has a legitimacy-enhancing role, especially in domestic politics. Islamist and conservative segments of the Turkish public who are sensitive to the Palestinian issue and Jerusalem expect the government to develop a discourse and policy based on Islam. As discussed previously, since religion can serve as a means of legitimacy, motivation, and persuasion both in foreign and domestic politics, religious statements in Turkish foreign policy centered around Palestine have played an important role for the motivation and persuasion of citizens.

Turkey was the first Muslim country to recognize the state of Israel and since then two countries have developed strategic partnerships in many fields. However, this did not prevent Turkey from pursuing a cautious and balanced policy in order not to be exposed to criticism from the Muslim world, especially Arab countries (Özcan, 2008, p. 119). As a result, relations between Turkey and Israel have been fragile and unstable marked by recurring diplomatic and political crises. These are the crisis between Erdogan and Shimon Peres at the Davos Summit in 2009, the Mavi Marmara crisis in 2010 or Israel's attacks on Gaza in the following years (Köprülü, 2019, pp. 93-94). The crisis in Davos in particular started a new era in Turkey-Israel relations characterized by an extensive use of religious discourse. After reciting the "Thou shall not kill" commandment from the Torah, Erdoğan stated "You know how to kill well. You killed children on the beaches. It is a crime against humanity to applaud those who killed these people. (Davos'ta Erdoğan-Peres Tartışması, 2009)", which exemplifies his criticism of Israel's aggression, not only with Islamic references, but also with the Jewish faith when suitable.

Although Turkey's policy on Palestine has been consistent due to Jerusalem and the Haram alSharif, which can be considered as a traditional stance of Turkish foreign policy, Turkey also accepts Israel's right to exist. In other words, we can say that rather than a policy which denies the right of existence of one-side of conflict, Turkish foreign policy stance has been based on a two-state solution. The speech of Israeli President Shimon Peres in the Turkish Grand National Assembly in 2007 (Peres $T B M M$ 'de Konuştu, 2007) also indicates that Turkey cannot afford to abandon its strategic partnership with Israel. This situation motivates Turkey to develop a policy framework that does not deny Israel's 
right to exist and despite the dominant character of the religious discourse towards Palestine in Turkish foreign policy and enables the peaceful handling of the issue. Similarly, Turkey's relations with Fatah and Hamas, the major players in Palestinian politics is not based on a categorical distinction between them despite their deep ideological differences, but rather on accepting both as the main representatives of the Palestinian issue (Güder \& Mercan, 2012, p. 77).

In light of the discussions above, we can argue that the role of religious discourse with regards to Turkey's policy on Palestinian-Israeli conflict is limited to the rhetorical level and is not a factor in the process of policy making and implementation. The most important reason for this is Turkey's desire to continue its strategic partnership with Israel despite its detrimental aspects, as an extension of its close relations with the Western world, although it is not likely to make concessions on the Palestinian issue. Emphasizing Zionism and Israel's attacks on innocent people rather than Jews or Judaism when constructing a religious foreign policy discourse is also related to a legitimacy concern both in domestic politics and towards the international community. For this reason, Turkey has been approaching the Palestinian-Israeli conflict with a peace-centered and cautious religious discourse that defends the right to life of both sides but without endangering those sites considered to be holy by Islam.

\section{Religious Discourse in Iran's Approach to the Palestine-Israel Issue}

One of the most concrete examples that contributed to the "revival of religion" discussions in the second half of the 20th century is the political transformation of Iran in 1979. The Islamic Revolution, which ended the Shah's regime, and the secular political structure of the state radically transformed the country's domestic and foreign politics by making Shia Islam its central element. In order to consolidate the revolution, the founding leader Khomeini redefined Iran's foreign policy based on the goal of "preserving national sovereignty and independence" and formulated in accordance with the dynamics of the revolution through anti-Westernism, anti-Americanism and "Neither East nor West" policy (Darabinia et al., 2017; Nia, 2012). Iran's foreign policy orientation changed not only on the global scale, but also within the context of the Islamic world. More specifically, its position towards Palestinian-Israeli conflict shifted with great hostility towards Israel. The existence of the state of Israel in the region and the Palestinian issue have always been on the agenda of Iran's foreign policy, both within the framework of its opposition to the US and the West, and Iran's claim to leadership in the Islamic world.

The leaders who came to power after Khomeini also adhered to his foreign policy approach in which religion was at the center, although not to the same degree of fervor in discourse and practice. The relative softening during the rule of these leaders along with the effect of the disintegration of the Soviet Union in the region, Islamic Republic's foreign policy prioritized the Iranian national interests and aimed to develop economic and security cooperation with other countries (Iranian President at Tehran Conference, 2005). In the post-Cold War context of American global dominance, Iran sought to indirectly normalize relations with the United States, called the "Great Satan" since the revolution and with its ally Israel, referred to as the "Little Satan" (Byman, 2001, pp. 7-10). During this period, the regime eased its rhetoric and ideological approach to foreign policy in order to prevent the isolation of Iran from the rest of the world (Khosrokhavar \& Roy, 2000, p. 30; Moslem, 2002, p. 144,148).

The foreign policy priorities of the period were to reduce the tension with the USA and Israel, to soften relations with the West, "dialogue between civilizations", developing relations with neighboring countries and cooperation with international organizations (Sinkaya, 2005, p. 32). The main reason for this trend of change in Iran's foreign policy was the international context created by the $9 / 11$ attacks. The negative perceptions of Islam and the Muslims developed and propagated after 
9/11 by conflating them with terrorism did not eliminate the religious discourse in Iran's foreign policy completely but reduced its emphasis. With regards to the conflict between Palestine and Israel, Iran softened and at times abandoned its anti-Israel and anti-Zionist discourse. In the post-9/11 period, President Khatami became one of the pioneers of the "dialogue between civilizations" discourse on a global scale, however his opposition to the accusations of terrorism and conflict on Islam and Muslims and his messages of peace through Islam did not yield any results. Iran's relations with the West and the United States have deteriorated further when in 2002 George W. Bush declared Iran as a part of the "Axis of Evil" along with North Korea and Iraq (National Security Strategy of United States of America 2002, 2002).

The foreign policy orientation adopted by leaders after Khomeini that was less radical, moderate, inclined to cooperation, and relatively distant to revolutionary ideals raised international expectation that Iran would eventually abandon its religious and revolutionary foreign policy. However, the election of Ahmadinejad as president in 2005 destroyed these expectations. Ahmadinejad's concrete and clear rhetoric targeting the U.S. and Israel, and pursuit of confrontational foreign policy in line with his hardline views increased the role of religion in shaping Iran's foreign policy discourse and practice.

Ahmadinejad's 'messianic' views based on his belief of the imminent return of the Hidden Imam (Ahdiyyih, 2008, pp. 30-31; Amuzegar, 2007; Gold, 2012), claims on his accession to power as signaling "a new Islamic revolution" and aiming "a return to revolutionary principles" (AFP, 2005) informed Iran's foreign policy discourse and strategy during his presidency. These religious elements were very much evident in his harsh approach towards Israel. Immediately after taking office, at a conference called "The World Without Zionism" in Tehran, he clearly revealed his views on Israel. His remarks on the necessity of 'erasing' Israel from the face of the earth (Fathi, 2005) in order for the salvation of the entire Islamic world ${ }^{4}$, especially Palestine, and his denial of the Holocaust (Ehteshami \& Zweiri, 2007, p. 110; The Guardian, 2005), his comments on 9/11 attacks as the collaborative work of the CIA, MOSSAD and the Zionists (Mottale, 2011, p. 268) have been elements of Iran's religious foreign policy towards Israel.

Islamic Republic's stance that the state of Israel is not legitimate and needs to be destroyed has to do with its consistent position of support for the Palestinian cause since the revolution. Iran has very seldom referred to Israel by its name, but more often used the terms "Zionist Regime", "Regime of Zionist Usurpers" or "Occupiers of Jerusalem" (Akbarzadeh \& Barry, 2016, p. 622). In 2008, Iran labeled Israel's attack on Gaza was as a genocide against the Palestinians.

Iran's stance towards the conflict between Palestine and Israel has three elements. First of all, religion clearly finds its place in its discourse. Secondly, Israel's right to exist is not recognized and is paired with Zionism. Thirdly, its policies do not encourage peace and reconciliation, but is based on conflict and even nourishes it. In this sense, Iran's attitude towards the problem also differs from Turkey's emphasis on a peaceful resolution.

It should also not be overlooked that religious elements of Iran's policy with regards to the Palestinian-Israeli conflict serves to shore up regime's domestic and international legitimacy. Even during periods of relative softening, the religious character of Iranian foreign policy has been preserved

\footnotetext{
4 https://www.memri.org/reports/iranian-president-tehran-conference-very-soon-stain-disgrace-ie-israel-willbe-purged-center, 28.10.2005,
} 
since the 1979 revolution. Even when moderate and reformist governments came to power aiming to improve Iran's relations, the sensitivity towards Palestine and Jerusalem and the anti-Israeli sentiment could not be flexed with the influence of the expectations of the society. In fact, the soft attitudes of these leaders on the issue contributed to their loss of legitimacy at home. After 2005, religion started to serve a pragmatic and legitimizing function in Iran's foreign policy. Although interpreted by many as aggressive, expansionist and mostly ideological (Amuzegar, 2007) ), religious pragmatism would be a more appropriate description of this period's foreign policy. Thus, it is safe to say that Iran's policy towards the Palestinian-Israeli conflict has been consistent despite changes in governments.

The persistent support of the Palestinian cause enabled Iran to claim a prominent place within the Islamic world when its other foreign policy positions created a rift with the Arab world and sometimes with the rest of Muslim community. Iran's hostility to the state of Israel and questioning of the Holocaust have strengthened its stance in the Arab world (Mottale, 2011). Similarly, Iran's Palestine policy contributed to its goals of forming an anti-Western front and strengthening its national and regional security (Djalili \& Kellner, 2011, p. 159). The opportunity offered by religion to provide legitimacy has been used by Iran in both domestic and foreign policy. With regards to the conflict between Israel and Palestine more specifically, Iran has pursued a foreign policy that advocates the Palestinian cause within the framework of religious conflict-based and pragmatism and denies the right of Israel to exist in order to avoid the negative effects of its international isolation and multi-faceted foreign policy and to gain legitimacy in domestic politics.

\section{CONCLUSION}

This article has examined the overlaps and differences between the role of religious discourses in shaping the foreign policies of Turkey and Iran towards the Palestinian-Israeli conflict. It argued that in both of the cases the legitimizing and motivating power of religion has been mobilized by leaders of these countries as an effective tool at both national and international levels. Through the use of religious arguments in the international relations of Turkey and Iran, Erdogan and Ahmadinejad respectively aimed to consolidate their constituencies and gain legitimacy in domestic politics, and to increase their influence and bargaining power of in regional and global politics. The ways in which religion has manifested in these countries' discourses and practices with regard to the PalestinianIsraeli conflict have emerged one of the main issue areas to assess and demonstrate the effect of religion in the foreign policy making and implementation.

Ankara and Tehran have largely similar motives in their stance on the Palestinian cause. The religious discourse centered on the protection of the holy sites of Jerusalem and the Haram al-Sharif clearly shapes the politics of both Turkey and Iran. However, they differ in their relationships with various Palestinian actors. While these countries' positions on Hamas overlap, the same cannot be said about Fatah. Hamas is backed by Iran and seen as legitimate by Turkey as a legitimate political actor in Palestine resisting the occupation of Israel. Turkey's use of religious discourse on the Palestinian issue has not led to a cooling of relations with Fatah which has a more secular character, however Islamic Republic's relation with this movement has been based on its categorical rejection of actors whom it deems to have a conciliatory approach towards Israel. Iran's religious discourse shapes its foreign policy strategy regarding this conflict which considers only the elements resisting the Zionist rule in the field as interlocutor.

Turkey and Iran pursue diametrically opposite strategies towards Israel. While Israel's right to exist as a nation-state has not come into question as a result of Turkey's use of religious discourse on the Palestinian issue, the denial of this right by post-revolutionary leaders has remained consistent. 
Turkey's criticism of Israel is limited to demands of respect towards the holy sites of Islam, protecting the lives of innocent Palestinians, and abandoning the expansionist occupation policy. Turkey's discourses on Israel are framed as resistance to its Zionist philosophy and practices, but not hostility towards it. In this respect, the religious discourse used by Turkey in the Palestinian-Israeli conflict can be summarized as constructive, peaceful, centered on both parties' right to exist, and within the framework of respect for religious values and norms. Iran's approach towards Israel, on the other hand, is dominated by an understanding that completely denies its right to exist that equates it completely with Zionism and this view inevitably brings about the destructive and conflict-centered religious discourse of Iran in the Israeli-Palestinian conflict.

\section{REFERENCES}

AFP. (2005, June 30). Iran's Ahmadinejad looks to export "new Islamic revolution." The Daily Star Lebanon. http://www.dailystar.com.lb/News/Middle-East/2005/Jun-30/67489-irans-ahmadinejad-looks-toexport-new-islamic-revolution.ashx

Ahdiyyih, M. (2008). Ahmadinejad and the Mahdi. Middle East Quarterly, 27-36.

Akbarzadeh, S., \& Barry, J. (2016). State Identity in Iranian Foreign Policy. British Journal of Middle Eastern Studies, 43(4), 613-629. https://doi.org/10.1080/13530194.2016.1159541

Amuzegar, J. (2007). The Ahmadinejad Era: Preparing for the Apocalypse. Journal of International Affairs, 60(2), $35-53$.

AFP. (2005, June 30). Iran's Ahmadinejad looks to export "new Islamic revolution." The Daily Star Lebanon. http://www.dailystar.com.lb/News/Middle-East/2005/Jun-30/67489-irans-ahmadinejad-looks-toexport-new-islamic-revolution.ashx

Ahdiyyih, M. (2008). Ahmadinejad and the Mahdi. Middle East Quarterly, 27-36.

Akbarzadeh, S., \& Barry, J. (2016). State Identity in Iranian Foreign Policy. British Journal of Middle Eastern Studies, 43(4), 613-629. https://doi.org/10.1080/13530194.2016.1159541

Amuzegar, J. (2007). The Ahmadinejad Era: Preparing for the Apocalypse. Journal of International Affairs, 60(2), 35-53.

Asad, T. (2003). Formations of the Secular: Christianity, Islam, Modernity. Stanford University Press.

Berger, P. L. (Ed.). (1999). The Desecularization of the World: Resurgent Religion and World Politics. Ethics and Public Policy Center ; W.B. Eerdmans Pub. Co.

Bush, G. W. (2002, January 29). Address Before a Joint Session of the Congress on the State of the Union. https://www.presidency.ucsb.edu/documents/address-before-joint-session-the-congress-the-statethe-union-22

Byman, D. (Ed.). (2001). Iran's Security Policy in the post-Revolutionary Era. RAND.

Cumhurbaşkanı Erdoğan Siyonizme Karşı Yahudiler Birliği heyetini kabul etti. (2019, September 23). https://www.aa.com.tr/tr/dunya/cumhurbaskani-erdogan-siyonizme-karsi-yahudiler-birligi-heyetinikabul-etti/1591049

Cumhurbaşkanı Erdoğan'dan Mescid-i Aksa Çağrısı. (2021, May https://www.trthaber.com/haber/gundem/cumhurbaskani-erdogandan-mescid-i-aksa-cagrisi580451.html

Darabinia, M., Marzband, R., \& Foroughiniya, H. (2017). Imam Khomeini's Foreign Policy: Conceptual Framework, Perspectives and Challenges. Journal of International Relations and Foreign Policy, 5(2), 32-38.

Davos'ta Erdoğan-Peres Tartışması. (2009, January 30). Amerika'nin Sesi | Voice of America - Turkish. https://www.amerikaninsesi.com/a/a-17-2009-01-30-voa1-88145527/872528.html

Davutoğlu, A. (2004). Stratejik Derinlik: Türkiye'nin Uluslararası Konumu. Küre Yayınları. 
Davutoğlu, A. (2008). Turkey's Foreign Policy Vision: An Assessment of 2007. Insight Turkey, 10(1), 77-96.

Dışişleri Bakanı Sayın Ahmet Davutoğlu'nun Türk Ocakları'nın Kuruluşunun 100. Yılını Kutlama Etkinlikleri Kapsamında Düzenlenen "Büyük Türkiye'ye Doğru” Sempozyumunda Yaptığı Konuşma. (2011, March 26). T.C. Dışişleri Bakanlığı. https://www.mfa.gov.tr/disisleri-bakani-sayin-ahmet-davutoglu_nun-turkocaklari_nin-kurulusunun-100_-yilini-kutlama-etkinlikleri-kapsaminda-duzenlenen.tr.mfa

Djalili, M.-R., \& Kellner, T. (2011). İran'ın Son İki Yüzyıllık Tarihi. Bilge Kültür Sanat.

Ehteshami, A., \& Zweiri, M. (2007). Iran and The Rise of Its Neoconservatives: The Politics of Tehran's Silent Revolution. I.B. Tauris.

Erdoğan "Siyonizm" ile Ilgili Sözlerine Açıklık Getirdi. (2013, March 20). CNN Türk. https://www.cnnturk.com/2013/guncel/03/20/erdogan.siyonizm.ile.ilgili.sozlerine.aciklik.getirdi/7008 37.0/index.html

Erdoğan'dan Kudüs Teklifi: 3 Dinin Temsilcilerinden Oluşan Bir Komisyon Yönetsin. (2021, May 17). Sondakika.com. https://www.sondakika.com/haber/haber-son-dakika-cumhurbaskani-erdogan-dankudus-14138226/

Fathi, N. (2005). Wipe Israel "off the map" Iranian says. The New York Times. https://www.nytimes.com/2005/10/27/world/africa/wipe-israel-off-the-map-iranian-says.html

Fox, J. (2001). Religion as an Overlooked Element of International Relations. International Studies Review, 3(3), 53-73. https://doi.org/10.1111/1521-9488.00244

Fox, J., \& Sandler, S. (2004). Bringing Religion into International Relations. Palgrave Macmillan US. https://doi.org/10.1057/9781403981127

Fox, J., \& Sandler, S. (2005). The Question of Religion and World Politics. Terrorism and Political Violence, 17(3), 293-303. https://doi.org/10.1080/09546550590929165

Fukuyama, F. (1992). The End of History and the Last Man. Free Press; Maxwell Macmillan Canada ; Maxwell Macmillan International.

Gold, D. (2012). The Emergence of Iran's Revolutionary Guards' Regime. Jerusalem Center for Public Affairs. https://jcpa.org/article/irans-revolutionary-guards/

Güder, S., \& Mercan, M. H. (2012). 2000 Sonrası Türk Dış Politikasının Temel Parametreleri ve Orta Doğu. İnsan ve Toplum, 2(3), 57-92.

Hagen, G. (2005). Legitimacy and World Order. In H. T. Karateke \& M. Reinkowski (Eds.), Legitimizing the Order: The Ottoman Rhetoric of State Power (1st Edition, pp. 55-83). Brill Academic Pub.

Haynes, J. (1994). Religion in Third World Politics. Rienner.

Haynes, J. (2005). Religion and International Relations after '9/11.' Democratization, 12(3), 398-413. https://doi.org/10.1080/13510340500126814

Haynes, J. (2007). Introduction to International Relations and Religion. Pearson Longman.

Haynes, J. (2008). Religion and Foreign Policy Making in the USA, India and Iran: Towards a Research Agenda. Third World Quarterly, 29(1), 143-165.

Huntington, S. P. (1993a). If Not Civilizations, What? Paradigms of the Post-Cold War World. Foreign Affairs, 72(5), 186-194. https://doi.org/10.2307/20045880

Huntington, S. P. (1993b). The Clash of Civilizations? Foreign Affairs, 72(3), 22. https://doi.org/10.2307/20045621

Huntington, S. P. (1996). The Clash of Civilizations and the Remaking of World Order. Simon \& Schuster.

Hurd, E. S. (2004). The Political Authority of Secularism in International Relations. European Journal of International Relations, 10(2), 235-262. https://doi.org/10.1177/1354066104042936

Hurd, E. S. (2008). The Politics of Secularism in International Relations. Princeton University Press. 
Iranian President at Tehran Conference: "Very Soon, This Stain of Disgrace [i.e. Israel] Will Be Purged From the Center of the Islamic World - and This is Attainable." (2005, November 28). MEMRI. https://www.memri.org/reports/iranian-president-tehran-conference-very-soon-stain-disgrace-ieisrael-will-be-purged-center

Johnston, D. (Ed.). (2003). Faith-Based Diplomacy: Trumping Realpolitik. Oxford University Press.

Johnston, D., Sampson, C., \& Center for Strategic and International Studies (Washington, D.C.) (Eds.). (1994). Religion: The Missing Dimension of Statecraft. Oxford University Press.

Juergensmeyer, M. (2003). Terror in the Mind of God: The Global Rise of Religious Violence (3rd ed., rev.updated). University of California Press.

Khosrokhavar, F., \& Roy, O. (2000). İran: Bir Devrimin Tükenişi. Metis yay.

Köprülü, N. (2019). Turkey's Identity and Foreign Policy in Transition since 2002: The Case Of Relations with Palestine. In M. Hatay \& Z. Tziarras (Eds.), Kinship and Diasporas in Turkish Foreign Policy: Examples from Europe, the Middle East and the Eastern Mediterranean (pp. 89-103). Peace Research Institute Oslo.

Koslowski, R., \& Kratochwil, F. V. (1994). Understanding Change in International Politics: The Soviet Empire's Demise and the International System. International Organization, 48(2), 215-247. https://doi.org/10.1017/S0020818300028174

Kratochwil, F. (2006). History, Action and Identity: Revisiting the 'Second' Great Debate and Assessing its Importance for Social Theory. European Journal of International Relations, 12(1), 5-29. https://doi.org/10.1177/1354066106061323

Luttwak, E. (1995). The Missing Dimension. In D. Johnston \& C. Sampson (Eds.), Religion, The Missing Dimension of Statecraft (1st edition, pp. 8-19). Oxford University Press.

Moslem, M. (2002). Factional Politics in post-Khomeini Iran (1st ed). Syracuse University Press.

Mottale, M. (2011). Iran's Clerical Regime’s 'Jewish Problem.' Democracy and Security, 7(3), 258-270.

National Security Strategy of United States of America 2002. (2002). https://georgewbushwhitehouse.archives.gov/nsc/nss/2002/

Nia, M. M. (2012). Discourse and Identity in Iran's Foreign Policy. Iranian Review of Foreign Affairs, 3(3), $29-64$.

Norris, P., \& Inglehart, R. (2004). Sacred and Secular: Religion and Politics Worldwide (1st ed.). Cambridge University Press. https://doi.org/10.1017/CBO9780511791017

Özcan, M. (2008). Harmonizing Foreign Policy: Turkey, the EU and the Middle East (1 edition). Routledge.

Ozkan, M. (2013). Turkey, Islamic Politics and the 'Turkish Model.' Strategic Analysis, 37(5), 534-538. https://doi.org/10.1080/09700161.2013.821245

Ozkan, M., \& Chatterjee, K. (2019). Islamic Values in Foreign Policy: Perspectives on 'Secular' Turkey and 'Islamic' Iran. In Krishnan Srinivasan, James Mayall, \& Sanjay Pulipaka (Eds.), Values in Foreign Policy: Investigating Ideals and Interests (pp. 115-134). Rowman \& Littlefield International.

Peres TBMM'de konuştu. (2007, November 13). www.haberturk.com. https://www.haberturk.com/gundem/haber/44145-peres-tbmmde-konustu

Petito, F., \& Hatzopoulos, P. (Eds.). (2003). Religion in International Relations: The Return from Exile (1st ed). Palgrave Macmillan.

Philpott, D. (2000). The Religious Roots of Modern International Relations. World Politics, 52(2), $206-245$. https://doi.org/10.1017/S0043887100002604

Riesebrodt, M. (2000). Fundamentalism and the Resurgence of Religion. Numen, 47(3), $266-287$. https://doi.org/10.1163/156852700511559

Schmitt, C. (2005). Political Theology: Four Chapters on the Concept of Sovereignty (University of Chicago Press ed). University of Chicago Press. 
Sinkaya, B. (2005). Devrimden Günümüze İran Dış Politikası'nın Dönüşümü. Mülkiyeliler Birliği Dergisi, 247(5-6).

Snyder, J. L. (Ed.). (2011). Religion and International Relations Theory. Columbia University Press.

Stern, J. (2003). Terror in the Name of God: Why Religious Militants Kill (1st ed). Ecco.

Taleblu, B. B. (2014, October 23). The Long Shadow of the Iran-Iraq War [Text]. The National Interest; The Center for the National Interest. https://nationalinterest.org/feature/the-long-shadow-the-iran-iraq-war11535

The Guardian. (2005). Holocaust a myth, says Iranian president. http://www.theguardian.com/world/2005/dec/14/iran.secondworldwar

Thomas, S. (2000). Religion and International Conflict. In K. R. Dark (Ed.), Religion and International Relations (pp. 1-23). Palgrave.

Thomas, S. M. (2003). Taking Religious and Cultural Pluralism Seriously. In P. Hatzopoulos \& F. Petito (Eds.), Religion in International Relations (pp. 21-53). Palgrave Macmillan US. https://doi.org/10.1057/9781403982360_2

Thomas, S. M. (2005). The Global Resurgence of Religion and the Transformation of International Relations. Palgrave Macmillan US. https://doi.org/10.1057/9781403973993

Toft, M. D., Philpott, D., \& Shah, T. S. (2011). God's Century: Resurgent Religion and Global Politics (1st ed). W.W. Norton. 